\title{
ARGUMENTAÇÃO JURÍDICA UTILIZADA PELOS TRIBUNAIS BRASILEIROS AO TRATAR DAS UNIÕES HOMOAFETIVAS *
}

Claudia Rosane Roesler e Paulo Alves Santos

LEGAL ARGUMENT USED BY BRAZILIAN COURTS TO DEAL WITH HOMOAFFECTIVE UNIONS

\section{RESUMO}

ESTE ARTIGO VERSA SOBRE A ARGUMENTAÇÃO DESENVOLVIDA PELOS TRIBUNAIS BRASILEIROS, SOBRETUDO A CORTE CONSTITUCIONAL, AO LIDAR COM QUESTÕES RELATIVAS ÀS UNIÕES HOMOAFETIVAS. INICIALMENTE, REALIZOU-SE UMA ANÁLISE DAS DECISÕES JUDICIAIS PROFERIDAS NOS CONFLITOS QUE ENVOLVEM O TEMA EM ÂMBITO ESTADUAL, OBSERVANDO OS POSICIONAMENTOS ADOTADOS PELOS TRIBUNAIS DE JUSTICAA E OS ARGUMENTOS UTILIZADOS POR ELES PARA JUSTIFICAR SUAS POSTURAS. OS DADOS COLHIDOS FORAM SISTEMATIZADOS E APRESENTADOS DE FORMA DESCRITIVA, SITUANDO O POSICIONAMENTO DAS CORRENTES INTERPRETATIVAS QUE SE DESENVOLVERAM A PARTIR DA CONTROVÉRSIA EM DEBATE. EM SEgUIDA, AVALIOU-SE A DECISÃo DO SUPREMO TRIBUNAL FEDERAL NO JULGAMENTO DA ADI 4.277, A FIM DE DETERMINAR COMO OS ARGUMENTOS SUSCITADOS NO DEBATE NACIONAL FORAM, OU NÃO, ENFRENTADOS PELA CORTE SUPREMA E O GRAU DE SOLIDEZ DA FUNDAMENTAÇÃO APRESENTADA PARA O ACÓRDÃO PROLATADO.

\section{PALAVRAS-CHAVE}

UnIÕES hOMOAFETIVAS; ARgumentaÇÃo JurídICA; JUdICIÁRIO BRASILEIRO; ADI 4.277; ENTIDADES FAMILIARES.

\begin{abstract}
THIS ARTICLE PROPOSES AN ANALYSIS OF THE ARGUMENTS DEVELOPED BY THE BRAZILIAN COURTS, ESPECIALLY THE CONSTITUTIONAL COURT, WHILE DEALING WITH ISSUES RELATING TO HOMOAFFECTIVE UNIONS. INITIALLY, WE CARRIED OUT AN ANALYSIS OF JUDICIAL DECISIONS MADE IN CONFLICTS INVOLVING THE ISSUE AT THE STATE LEVEL, NOTING THE POSITIONS ADOPTED BY THE COURTS AND THE ARGUMENTS USED BY THEM TO JUSTIFY THEIR POSITIONS. THE COLLECTED DATA WERE ORGANIZED AND PRESENTED IN A DESCRIPTIVE MANNER, PLACING THE POSITION OF INTERPRETIVE TRENDS THAT HAVE DEVELOPED AROUND THE CONTROVERSY. THEN IT IS EVALUATED THE DECISION OF THE SUPREME COURT IN THE TRIAL OF ADI 4.277, IN ORDER TO DETERMINE HOW THE ARGUMENTS RAISED IN THE NATIONAL DEBATE WERE, OR NOT, FACED BY THE SUPREME COURT AND THE DEGREE OF ROBUSTNESS OF THE REASONS GIVEN FOR THE JUDGMENT.

\section{KEYWORDS}

HOMOAFFECTIVE UNIONS; LEGAL ARGUMENTATION; BRAZILIAN JUDICIARY; ADI 4.277.

\section{A União estável no ORdenamento Jurídico brasileiro}

As relações familiares geram diversas implicações no âmbito dos direitos personalíssimos e patrimoniais, razão pela qual recebem especial atenção normativa. O complexo dessas relações encontra amparo no direito de família, que se dedica ao estudo e à tutela dos efeitos jurídicos advindos das entidades familiares. 
A atuação do legislador brasileiro, firme na tradição romano-canônica, sempre se pautou pela supremacia do modelo familiar heteronormativo instituído pelo casamento. Contudo, ao longo de nossa história jurídica, esta perspectiva vem sendo rompida, sobretudo em razão da pressão advinda da dinâmica das relações sociais.

A esse respeito, a Constituição Brasileira de 1988 inseriu no ordenamento normativo pátrio, de forma inovadora, um modelo familiar flexível, conferindo tratamento legislativo às chamadas "uniões estáveis". O novo texto constitucional dispôs:

Art. 226. A família, base da sociedade, tem especial proteção do Estado. [...]

$\S 3^{\circ}$ Para efeito da proteção do Estado, é reconhecida a união estável entre o homem e a mulher como entidade familiar, devendo a lei facilitar sua conversão em casamento. (BRASIL, 1988)

Ao regular este dispositivo da Constituição, o Código Civil brasileiro erigiu como requisitos para a configuração da união estável a convivência pública, contínua, duradoura e estabelecida com o objetivo de constituir família entre um homem e uma mulher (BRASIL, 2002).

A publicidade exige que a constituição da união estável seja fato incontroverso e notório perante sociedade, não podendo ser mantido em segredo. A continuidade se relaciona a uma estabilidade de convivência que é intrínseca a este modelo familiar, embora não haja a exigência de prazo mínimo para sua configuração. O objetivo de constituir família requer dos companheiros um "firme propósito" de conferir àquele relacionamento um grau de compromisso compatível com a responsabilidade inerente aos institutos familiares. Por fim, a diversidade de sexos é elemento diretamente relacionado à tradicional opção do direito brasileiro (GONÇALVES, 2009).

Esses são requisitos objetivos e subjetivos que permitem diferenciar uma mera relação eventual, ou uma relação duradoura despida de seriedade, daquela união que o Estado reconhece como entidade familiar. Além disso, a lei não autoriza a existência de união estável entre pessoas impedidas para o casamento, pois a parte final da norma constitucional direciona a atividade legislativa no sentido de facilitar a conversão daquela para este.

Contudo, os limites da união estável aparecem bastante sinuosos em casos nos quais a aplicação da lei vigente não ocorre de maneira tão clara. Os critérios escolhidos pela lei tornam bastante árdua a tarefa do intérprete em reconhecer se há publicidade suficiente, se entre os companheiros havia ânimo de constituir família ou se o tempo de relacionamento é satisfatório ou não.

É dentro desses casos limítrofes que se insere a temática da possibilidade de existência de uma união estável homoafetiva. Embora tenha sido explicitado pela Constituição que esta entidade familiar ocorreria entre "homem e mulher", forte corrente 
interpretativa tem considerado que este dispositivo deve ser problematizado e compreendido de forma mais ampla, à luz do princípio constitucional da igualdade.

Este estudo se dedica à análise do comportamento da jurisprudência brasileira diante dessa controvérsia e à avaliação das razões adotadas pelo Supremo Tribunal Federal na busca pela solução dessa disputa hermenêutica. No contexto da análise, procuraremos compreender os diversos argumentos formulados na tentativa de solucionar a questão, ao passo que, ao avaliarmos a decisão da Suprema Corte, buscaremos determinar o nível de coerência da decisão e investigar o grau de solidez dos fundamentos apresentados. O trabalho parte, assim, de uma distinção proposta por Manuel Atienza (2013) entre analisar e avaliar uma argumentação, compreendendo que a primeira fase de todo o trabalho de discussão das decisões judiciais deve ser centrado na compreensão de sua estrutura argumentativa, enquanto a segunda parte (e em sequência à primeira), é destinada à sua valoração. ${ }^{1}$

\section{ANÁlise dA JURISPRUDÊNCIA DOS TRIBUNAIS BRASILEIROS}

A discussão acerca do tratamento jurídico a ser conferido às uniões entre pessoas do mesmo sexo assumiu contornos diversos em cada país no qual essa questão foi suscitada. Desde as respostas mais inclusivas até a negação de qualquer proteção jurídica, os Estados tiveram de designar qual a posição que essas relações teriam em seus ordenamentos jurídicos. ${ }^{2}$

No Brasil, embora haja legislação dispersa sobre o assunto, ${ }^{3}$ a construção do regime jurídico aplicável às famílias homoafetivas se deu principalmente pela via jurisprudencial. Assim, compreender a forma como os tribunais brasileiros enfrentaram esta controvérsia significa conhecer o próprio desdobramento da inserção deste instituto no direito pátrio.

Por essa razão, esta pesquisa propôs, inicialmente, a realização de uma análise dos argumentos utilizados nos debates acerca das uniões homoafetivas travadas nos tribunais estaduais e do Distrito Federal. Com essa investigação, objetiva-se apreender o estágio de desenvolvimento em que se encontrava a jurisprudência brasileira sobre o tema no período anterior à decisão do Supremo Tribunal Federal, que apreciou a questão na via do controle abstrato de constitucionalidade.

O método utilizado para diagnosticar o comportamento dos órgãos judicantes foi a análise individualizada de julgamentos emanados dos tribunais que compõem a segunda instância da jurisdição comum. Esses resultados foram obtidos por meio de buscas nas páginas eletrônicas que as cortes mantêm na internet e os acórdãos encontrados foram submetidos a uma apreciação de sua estrutura argumentativa, com base modelo proposto por Stephen Toulmin (2001).

O termo empregado para efetuar a busca foi "união homoafetiva". De fato, a despeito de outras denominações que as uniões entre pessoas do mesmo sexo tenham 
recebido, esta expressão, cunhada pela desembargadora gaúcha Maria Berenice Dias (2000), foi rapidamente assimilada na prática jurídica e mostra-se tecnicamente mais apropriada à discussão que se trava na esfera do direito de família contemporâneo, no qual o afeto possui lugar de destaque.

O período a ser pesquisado foi fixado sobre duas balizas: a necessidade de um lapso temporal suficiente para observar o desenrolar do comportamento do tribunal e a existência de um substrato legislativo comum e estável sobre a temática. Dessa forma, tomou-se como marco inicial a entrada em vigor da Lei n. 10.406/2002 (Código Civil atual) e como termo final o último dia do ano anterior àquele no qual o Supremo Tribunal Federal julgou a ADI 4.277, cujo resultado possui efeito vinculante. ${ }^{4}$ Portanto, foram analisados resultados de 11/01/2003 a 31/12/2010.

Além disso, somados aos critérios já delineados, foram utilizados critérios de seleção material dos julgamentos a serem considerados na pesquisa. O objetivo deste filtro de relevância consistia em retirar do rol de decisões aquelas em que: a) a temática das uniões homoafetivas tenha sido versada de forma paralela ou incidental, sem qualquer reflexo na razão de decidir do julgamento; b) a discussão sobre matéria fática impossibilitou a discussão acerca do regime jurídico das uniões homoafetivas; c) acórdão de embargos de declaração que apenas reafirmavam o que já havia sido decidido pelo tribunal, tendo em vista que a decisão desses recursos compõe o próprio acórdão principal. ${ }^{5}$

Com base nesses parâmetros, a busca inicial nos sites dos tribunais retornou 325 resultados. Após a aplicação do filtro material, 139 resultados foram considerados irrelevantes e descartados, de forma que a amostra definitiva para a análise ficou composta de 186 resultados, cuja distribuição geográfica pode ser observada nos seguintes gráficos:

gráfico 1 - Percentual De Decisões releVantes E IRrelevantes

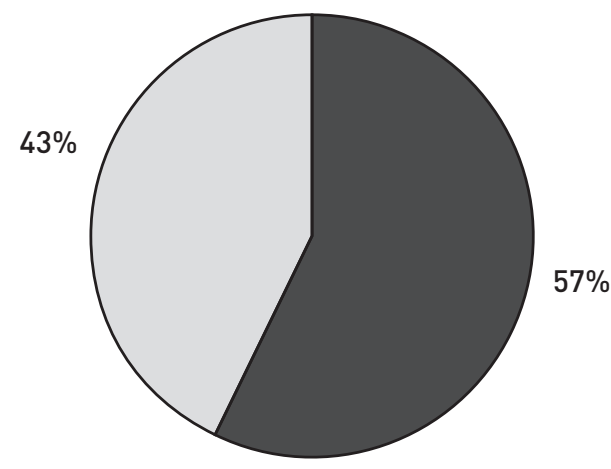

DESCARTADOS

RELEVANTES 


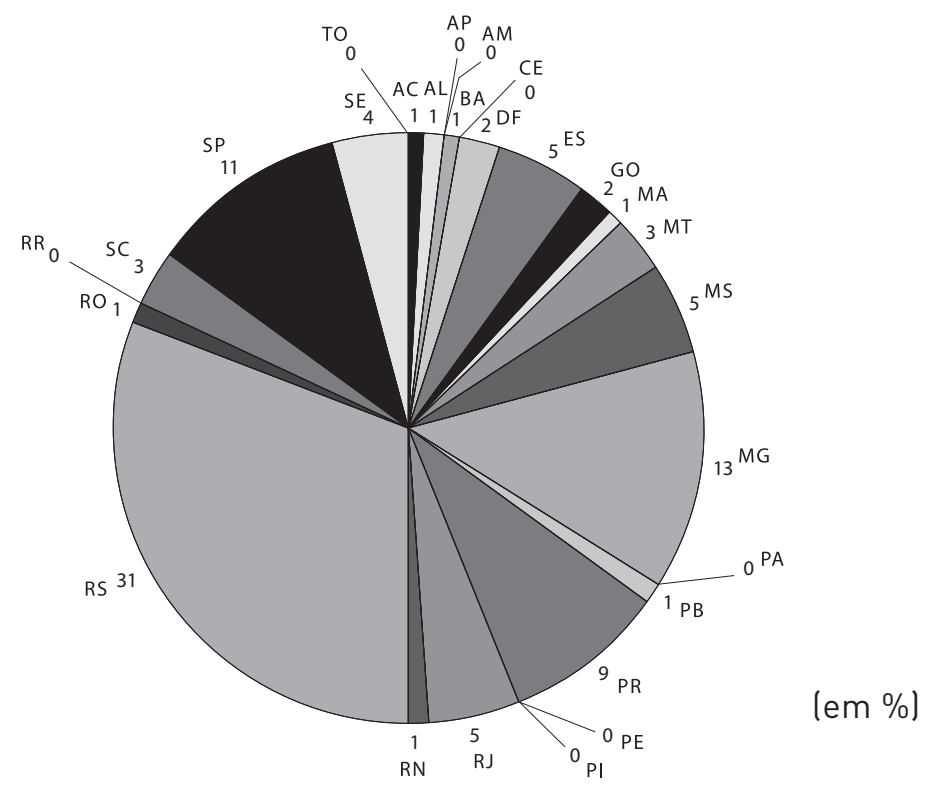

Como se vê, há uma acentuada diferença entre o número de casos julgados pelos estados federados. Enquanto alguns tribunais analisaram a controvérsia em diversas oportunidades, existem outros, como o Tribunal de Justiça do Tocantins, que jamais foram instados a se manifestar.

Para justificar esta disparidade, deve-se levar em consideração, além das diferenças populacionais e da dificuldade de acesso à justiça que se apresenta de forma mais frequente em alguns locais, o nível de informação disponível e o grau de influência exercida pelo preconceito em cada unidade federativa. De fato, ingressar com uma ação judicial buscando conferir efeitos jurídicos a uma relação homoafetiva pode significar enfrentar uma série de tabus, cuja força é diferenciada nas diversas regiões do país.

Ademais, como a pesquisa abrange decisões tomadas no segundo grau de jurisdição, o número de recursos que sobe aos tribunais pode variar conforme a maior ou menor tranquilidade com que essas questões são enfrentadas na primeira instância.

Nesse ponto, é importante destacar que esses recursos, em geral, são manejados: a) pelo próprio casal homoafetivo, que se volta contra a sentença que rejeita a possibilidade de equiparação com a união estável; b) por um dos companheiros homoafetivos ou pelos herdeiros de um dos companheiros falecidos, nos pedidos de dissolução 
da união homoafetiva nos moldes da união estável; e c) pelo Ministério Público, que atuou tanto em um sentido quanto no outro.

Apesar dessas dificuldades, o número de casos no decorrer do período abrangido pela pesquisa aumentou consideravelmente. No ano de 2003, foram apenas sete registros de julgamentos que envolveram a questão, ao passo que em 2010 a matéria foi pautada 45 vezes. A evolução da quantidade de julgados ao longo do tempo pode ser verificada no gráfico a seguir:

\section{GRÁFICO 3 - QUANTIDADE DE DECISÕES RELEVANTES NO DECORRER DO PERÍODO DE PESQUISA}

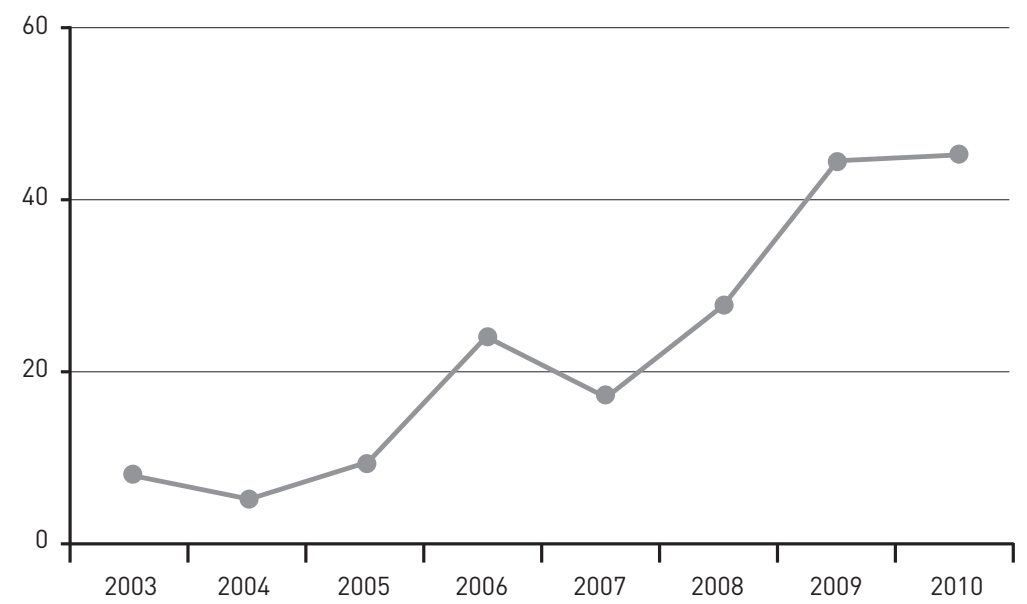

Percebe-se que, enquanto a corrente que defendia a equiparação encontrava lugar em alguns tribunais pioneiros, como o Tribunal de Justiça do Rio Grande do Sul, o número de pessoas que se interessavam em mover ações nesse sentido era atraído pela possibilidade de procedência da ação. Dessa forma, a aceitação da união homoafetiva como entidade familiar passava de teoria completamente impossível para a condição de questão juridicamente controversa, o que permitia o efetivo debate sobre o tema e encorajava um número maior de litigantes.

A esse respeito, deve-se notar a quantidade de julgamentos nos quais a corte estadual se limitava a afirmar a possibilidade jurídica do pedido de reconhecimento da união homoafetiva como união estável, determinando ao juízo da causa que realizasse nova análise da questão. Tais decisões afastavam a sentença de extinção da ação sem resolução do mérito, afirmando ser admissível, em tese, o pedido formulado pelos casais 
homossexuais. Contudo, o fato de ser possível não significava que, no mérito, essa fosse a solução jurídica a ser adotada.

De fato, ao julgar dessa forma, os tribunais apenas afirmavam o dever de o juiz analisar a tese apresentada, por que ele não poderia deixar de pronunciar o direito afirmando a existência de lacuna na lei. A esse respeito, ressaltou o Desembargador Elias Camilo, do Tribunal de Justiça de Minas Gerais:

Assim, in casu, cumpre ressaltar que, em que pese não ter nosso ordenamento jurídico pátrio consagrado, expressamente, as uniões homoafetivas, ou seja, entre pessoas do mesmo sexo, inexiste, também, qualquer vedação no sentido de não poder tal união surtir efeitos civis, o que, por evidente, não pode ser tido como ausência de direito, em especial considerando-se que, nos casos em que verificada a omissão da lei, mostra-se possível a aplicação da analogia, dos costumes e dos princípios gerais de direito, nos termos do disposto nos arts. $4^{\circ}$ da LICC e 126 do CPC.

[...]

Desta forma, vê-se que, inexistindo no ordenamento positivo brasileiro qualquer proibição expressa de reconhecimento de união homoafetiva e concessão de efeitos civis à esta, in casu, o pedido mostra-se, sob uma visão abstrata, suscetível de acolhimento ou rejeição, merecendo, portanto, reforma a sentença de primeiro grau que indeferiu a inicial por carência de ação.

Por tais razões de decidir, dou provimento ao recurso para, cassando a sentença impugnada, determinar o regular processamento do feito. ${ }^{6}$

Em verdade, a doutrina considera juridicamente impossível apenas o pedido expressamente vedado pelo ordenamento jurídico, pois nos demais casos o juiz poderá valer-se da analogia, dos costumes e dos princípios gerais do direito para solucionar a lide. ${ }^{7}$

Todavia, a conclusão de que a discussão acerca das uniões homoafetivas é juridicamente possível não é pacífica. Há quem, por outra perspectiva, enxergue no silêncio do constituinte uma vedação implícita ao reconhecimento da união homoafetiva como entidade familiar equiparada à união estável, conforme ressaltou a Desembargadora Maria do Rocio, do Tribunal de Justiça catarinense:

Trata-se de actio por meio da qual a apelante pretende o reconhecimento de união homoafetiva. Todavia, tal pretensão não se mostra juridicamente possível, uma vez que a legislação em vigor não a ampara.

A propósito, observe-se que o $\S 3^{\circ}$ do art. 226 da Constituição Federal estabelece que "para efeito da proteção do Estado, é reconhecida a união estável 
entre o homem e a mulher como entidade familiar, devendo a lei facilitar sua conversão em casamento."

$[\ldots]$

Verifica-se, portanto, que o conteúdo das mencionadas normas estabelecem expressamente como um dos requisitos à configuração da união estável e seu reconhecimento como entidade familiar a convivência entre homem e mulher, ou seja, deve haver a diversidade de sexos. Afasta-se, desta forma, qualquer possibilidade de se reconhecer tal instituto em relação às pessoas do mesmo sexo, o que caracteriza o pedido exordial como juridicamente impossível, não se podendo aplicar a analogia na hipótese, como pretende a apelante (grifos acrescidos). ${ }^{8}$

Essa divergência de entendimentos acerca de uma questão meramente preliminar é um prelúdio do conflito de jurisprudência sobre o mérito da controvérsia. Constatou-se, sem muito esforço, a inexistência de uma solução pacificada sobre o tratamento jurídico a ser conferido às uniões homoafetivas. As conclusões a que chegaram os diversos tribunais foram diametralmente opostas, sendo comum haver, em um mesmo órgão julgador, decisões em sentidos opostos sucedendo-se no tempo.

Ao final, verificou-se que, de todos os acórdãos analisados, 56\% admitiam a equiparação entre as uniões estáveis e as uniões homoafetivas de alguma forma. ${ }^{9}$ Os demais, 44\%, rechaçavam esta tese. No decorrer do período pesquisado, é impossível identificar uma jurisprudência dominante e estável, conforme se infere do gráfico a seguir, que mostra o desenrolar das decisões no tempo:

\section{GRÁFICO 4 - QUANTIDADE DE DECISÕES FAVORÁVEIS E DESFAVORÁVEIS NO DECORRER DO PERÍODO DE PESQUISA}
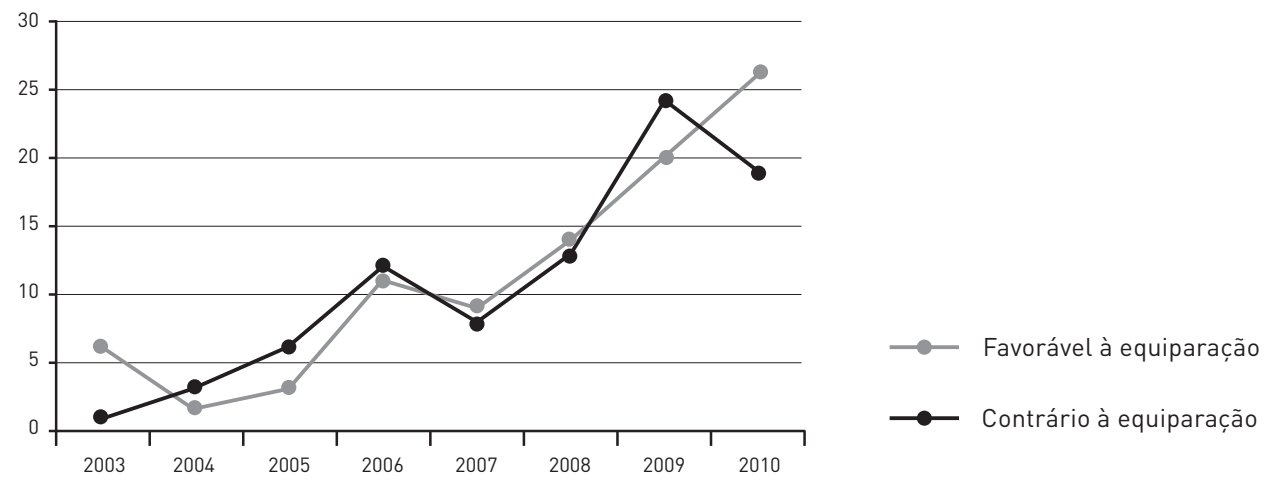
Entretanto, no meio do embate jurisprudencial, há tribunais que se destacaram pelo posicionamento firme em um sentido ou em outro. Essas cortes transformaram-se em referências para as demais, liderando verdadeiros "blocos" em defesa de cada uma das teses.

Um exemplo é o Tribunal de Justiça do Distrito Federal e Territórios, que nas nove vezes em que decidiu a questão manifestou-se contrário à possibilidade de equiparação entre a união estável e a união homoafetiva. Já no final de 2010, apenas alguns meses antes de o Supremo Tribunal Federal pacificar a questão em sentido contrário, a Corte distrital mantinha sua posição de que a união homoafetiva não poderia receber tratamento analógico à união estável, contrariando, inclusive, precedentes do Superior Tribunal de Justiça:

Ocorre que, de acordo as normas insculpidas nos artigos, 226, $\S 3^{\circ}$, da Constituição Federal e o artigo 1.723 do Código Civil, é inviável o reconhecimento da união estável entre pessoas do mesmo sexo, pois esta só poderia ser constituída por pessoas de sexo diferente. Assim, dispõe os citados dispositivos:

[...]

Com efeito, não obstante o entendimento que vem sendo consolidado no Superior Tribunal de Justiça no sentido de autorizar a adoção por pessoas que vivem em união homoafetiva, certo é que, diante da ausência de permissão constitucional ou legal para se reconhecer a união estável entre pessoas do mesmo sexo, fica inviabilizada a adoção conjunta da menor pelas demandantes, ora agravantes. (Voto vencedor do Des, João Batista Teixeira, AGI 2010.00.2.006328-2, $3^{\mathrm{a}}$ Turma Cível, data de julgamento: 27/10/2010, grifos acrescidos)

De outro lado, o Tribunal de Justiça do Rio Grande do Sul, apenas no ano de 2006, proferiu seis decisões favoráveis à equiparação. Os primeiros acórdãos do Tribunal a conferir tratamento analógico às uniões homoafetivas podem ser encontrados já no primeiro ano abrangido pela delimitação temporal da pesquisa (2003), por exemplo:

As entidades familiares referidas na Constituição não encerram uma relação hermética, fechada ou clausulada e nela se podem incluir outras que preencham determinados requisitos.

[...]

O objeto de norma não é a família, como valor autônomo, em detrimento das pessoas humanas que a integram, já que antes, a proteção se voltava para a paz doméstica, considerando-se a família fundada no casamento com um bem em si mesmo. 
Destarte, o caput do art. 226 é cláusula geral de inclusão, não sendo lícito excluir qualquer entidade que preencha os requisitos da afetividade, estabilidade e notoriedade, sendo as famílias ali arroladas meramente exemplificativas, embora as mais comuns.

As demais comunidades se acham implícitas, pois se cuida de conceito constitucional amplo e indeterminado, a que a experiência de vida há de concretizar, conduzindo à tipicidade aberta, adaptável, dúctil, interpretação que se reforça quando o preceito constitucional usa o termo "também", contido no artigo 226, 4 , que significa "da mesma forma”, "outrossim”, exprimindo-se uma ideia de inclusão destas unidades, sem afastar-se outras não previstas.

Assim, pode-se concluir que, mesmo sem lei que as regule, as uniões homoeróticas são reconhecidas pela Constituição como verdadeiras entidades familiares, para alguns como entidades distintas, em vista de sua natureza e para outros, onde ainda me filio, como verdadeiras uniões estáveis. (Voto Vencedor do Des. José Carlos Teixeira, Apelação 70005488812, 7ª Câmara Cível, data de julgamento: 25/06/2003, grifos acrescidos)

Todavia, embora os precedentes desses dois tribunais sejam reproduzidos em boa parte das decisões investigadas, é necessário observar que no âmbito interno das Cortes inexiste consenso absoluto sobre questão.

No Distrito Federal, em todos os julgamentos que participou, a Desembargadora Nídia Corrêa defendeu arduamente a tese contrária àquela majoritária em seu tribunal. Em seus votos, ela destacava que, em sua concepção, "deixar de reconhecer a existência de união estável entre duas pessoas, simplesmente por serem do mesmo sexo, atenta contra os princípios da dignidade da pessoa humana, por se tratar de uma conduta discriminatória e preconceituosa”. 10

No caso do Rio Grande do Sul, a questão da divergência é ainda mais emblemática. Em 2009, foram três decisões contrárias e três favoráveis à equiparação. Dessas seis decisões, cinco emanaram do mesmo órgão julgador.

No cerne dessa disputa interpretativa estão os diversos argumentos acolhidos pelos julgadores para justificar suas posições acerca do correto tratamento jurídico a ser conferido às uniões homoafetivas. A partir da classificação proposta por Neil MacCormick (2008), passamos a fazer uma análise dessas assertivas.

Inicialmente, percebe-se em ambos os lados a tentativa de alcançar a "vontade da Constituição". Entretanto, enquanto a corrente contrária defende que este objetivo pode ser alcançado a partir da literalidade da lei, os defensores da equiparação afirmam que este propósito deve ser buscado por meio de uma interpretação sistemática e principiológica do texto constitucional.

Assim, o argumento literal, na forma frequentemente encontrada na jurisprudência 
brasileira sobre o assunto, sustenta que a expressão utilizada na norma é clara, não havendo necessidade de maiores considerações a esse respeito. Por esse viés, ao explicitar o termo "entre homem e mulher", o constituinte originário não o fez em vão, mas com o objetivo de impedir a extensão deste instituto a qualquer arranjo que não preenchesse esta exigência específica.

Ocorre, nesse ponto, uma intersecção entre o argumento teleológico e o literal. Conforme se verificou no curso desta pesquisa, as espécies argumentativas geralmente não se apresentam de forma pura. Há, na verdade, argumentações híbridas, formadas por argumentos que partem de perspectivas diferentes, o que demonstra a complexidade da atividade argumentativa empreendida.

No caso em análise, o argumento literalista é usado, na verdade, como suporte para uma argumentação teleológica. Esta argumentação literal-teleológica é recorrente e fundamenta-se na ideia de que a lei não utiliza palavras inúteis. Portanto, se foram usadas determinadas palavras na formulação do texto normativo, a norma que dele se extrai deve valorizar os termos literais utilizados, pois eles foram escolhidos pelo legislador com um objetivo específico. Caso contrário, a lei haveria utilizado termos distintos, com o fim de alcançar objetivos diversos.

Este entendimento pode ser ilustrativamente representado pelo seguinte trecho jurisprudencial:

À luz do art. 226, $\S 3^{\circ}$, da Constituição Federal, a união estável, para efeito de proteção do Estado, é aquela havida entre homem e mulher como entidade familiar.

$[\ldots]$

A diversidade de sexo continua a ser requisito fundamental tanto para a celebração do casamento, quanto para o reconhecimento da união estável, razão pela qual não se pode conceber a mesma natureza jurídica desses institutos às relações homoafetivas.

Não se trata, no entanto, de mera omissão legislativa passível de interpretação analógica extensiva. O dispositivo constitucional, ao declarar expressamente a proteção do Estado apenas à união estável existente entre homem e mulher, excluiu dessa proteção as relações havidas entre pessoas do mesmo sexo, caso contrário, as teria expressamente contemplado, conforme o fez com as relações heterossexuais.

Não pode o julgador ir além do que quis o legislador. (Voto vencedor do Desembargador Célio César. TJMG, Apelação 1.0024.07.764088-6/001, j. 04/12/2008, grifos acrescidos)

Em outra vertente, o argumento sistêmico se uniu à argumentação por princípios, a fim de afastar o entendimento literal que surge à primeira vista. 
De fato, na busca pela melhor interpretação possível, os princípios do sistema jurídico desempenham um papel fundamental. Eles são, por definição, elementos que permitem a exata compreensão das regras, conferindo-lhes um sentido harmônico (SUNDFELD, 2005). É exatamente nesse critério que os argumentos favoráveis à equiparação entre as uniões estáveis heteroafetivas e homoafetivas se tornam mais densos, justamente pelo fato de os princípios serem normas que não apresentam em sua estrutura situações fáticas determinadas de aplicação (DWORKIN, 2010).

A partir dessa perspectiva, assume-se o ordenamento jurídico constitucional como um sistema uno e coeso, cujas ideias centrais residem nos princípios (SUNDFELD, 2005). Assim, o verdadeiro sentido da expressão utilizada pelo legislador somente pode ser averiguado dentro do contexto em que a norma está inserida, invocando-se, sempre que necessário, os princípios do sistema normativo como instrumento de compatibilização ou, em último caso, exclusão da regra incompatível.

Como resultado, segundo os defensores da equiparação, não se poderia conceber que um texto constitucional que possui caráter inclusivo e abrangente em matéria de família fosse utilizado para negar direitos às uniões homoafetivas.

Pelo contrário, a harmonização deste dispositivo específico da Constituição com as demais disposições constitucionais, à luz dos princípios da igualdade, da liberdade e da dignidade humana, revelaria que o texto constitucional constitui, por si só, fundamento jurídico suficiente para equiparar às uniões homoafetivas às uniões estáveis.

Este posicionamento é adotado no seguinte julgamento:

A Constituição Federal proclama o direito à vida, à liberdade, à igualdade e à intimidade (art. $5^{\circ}$, caput) e prevê como objetivo fundamental, a promoção do bem de todos, "sem preconceitos de origem, raça, sexo, cor, idade e quaisquer outras formas de discriminação” (art. $3^{\circ}$, IV). Dispõe, ainda, que “a lei punirá qualquer discriminação atentatória dos direitos e liberdades fundamentais” (art. 5, XLI). Portanto, sua intenção é a promoção do bem dos cidadãos, que são livres para ser, rechaçando qualquer forma de exclusão social ou tratamento desigual.

Outrossim, a Carta Maior é a norma hipotética fundamental validante do ordenamento jurídico, da qual a dignidade da pessoa humana é princípio basilar vinculado umbilicalmente aos direitos fundamentais. Portanto, tal princípio é norma fundante, orientadora e condicional, tanto para a própria existência, como para a aplicação do direito, envolvendo o universo jurídico como um todo. Esta norma atua como qualidade inerente, logo indissociável, de todo e qualquer ser humano, relacionando-se intrinsecamente com a autonomia, razão e autodeterminação de cada indivíduo.

[...] 
Por conseguinte, a Constituição da República, calcada no princípio da dignidade da pessoa humana e da igualdade, se encarrega de salvaguardar os interesses das uniões homoafetivas. Qualquer entendimento em sentido contrário é que seria inconstitucional. E quanto à tutela específica dessas relações, aplica-se analogicamente a legislação infraconstitucional atinente às uniões estáveis. (Voto vencedor da Desembargadora Maria Berenice Dias. TJRS, Apelação 70012836755, data de julgamento: 21/12/2005)

No campo da argumentação por analogia, as correntes interpretativas divergiram sobre qual instituto mais se aproximava às relações homoafetivas. Aqueles que se opuseram à equiparação dessas relações às uniões estáveis justificavam que os relacionamentos homoafetivos, embora estivessem fora do âmbito do direito de família, encontravam respaldo jurídico na legislação obrigacional. Dessa forma, a união homoafetiva deveria ser tutelada em analogia com as sociedades de fato. Nesse sentido:

Certo é que, a inexistência de regime jurídico próprio a disciplinar a parceria homossexual há de levar, pelo emprego da analogia, à aplicação das normas que integram o direito das obrigações.

Assim o afirmo porque aspectos comuns fundamentais aproximam-na da sociedade de fato: a) não constitui elemento relevante a circunstância de serem os conviventes do mesmo sexo; b) deve haver união de esforços pessoais e/ou materiais, para a obtenção de fim comum e; c) é mister a mútua cooperação dos parceiros. (Voto vencedor da Des. Diva Lucy. TJDFT, AGI 2008.00.2.012928-9, 5 Turma Cível, data de julgamento: 18/03/2009, grifos acrescidos)

Contudo, o pensamento diverso repele de forma veemente esta interpretação. Segundo os julgadores que se alinham a esse entendimento, o traço que identifica tanto a união estável quanto a união homoafetiva é o vínculo personalíssimo que se forma entre as pessoas que participam desses institutos. Esse vínculo possui natureza comum em todas as entidades familiares e se manifesta por meio do exercício da afetividade entre os componentes da família. Portanto, tal realidade não guardaria qualquer semelhança com o ânimo associativo de uma organização com fins lucrativos, sendo mais adequada sua analogia com os institutos do direito de família.

Há, ainda, a abordagem da questão pelo prisma da harmonização contextual (MACCORMICK, 2008). Esta estratégia argumentativa, por sua vez, consiste na submissão do conceito jurídico em debate a um esquema normativo mais amplo, com o objetivo de verificar, dentro de um conjunto de regras relacionadas, qual interpretação melhor se adequaria dentro do todo legislativo. 
Partindo desse ponto de vista, os defensores da união estável homoafetiva argumentam que o direito civil-constitucional, na forma concebida após a Constituição de 1988, possui uma série de disposições que vedam a utilização da orientação sexual dos indivíduos como critério de diferenciação para fins jurídicos. Nesse sentido, é comum invocar como referência regras relacionadas à igualdade jurídica dos cônjuges, a existência de modelos familiares não vinculados a relacionamentos heteroafetivos e a primazia dos princípios da afetividade e do livre planejamento familiar dentro da legislação pertinente ao direito de família.

Com base nesse espeque, os intérpretes que se filiam à corrente mais progressista consideram estar suficientemente demonstrado que qualquer interpretação que negue às relações homoafetivas o caráter familiar certamente implicará desarmonia com restante das normas referentes à matéria.

Este argumento foi especialmente reforçado após a edição da Lei n. 11.340/2006 (Lei Maria da Penha), que inovou ao apresentar um conceito de família que não mais se baseia na enumeração dos tipos familiares, mas nos elementos constitutivos presentes em qualquer entidade familiar. Preceitua o referido diploma normativo:

Art. $5^{\circ}$ Para os efeitos desta Lei, configura violência doméstica e familiar contra a mulher qualquer ação ou omissão baseada no gênero que lhe cause morte, lesão, sofrimento físico, sexual ou psicológico e dano moral ou patrimonial:

[...]

II - no âmbito da família, compreendida como a comunidade formada por indivíduos que são ou se consideram aparentados, unidos por laços naturais, por afinidade ou por vontade expressa;

$[\ldots]$

Parágrafo único. As relações pessoais enunciadas neste artigo independem de orientação sexual. (Grifos acrescidos)

Contudo, os que se opõem ao entendimento de que a união homoafetiva constitui entidade familiar asseveram que as disposições da Lei Maria da Penha são específicas e não podem ser entendidas como regra geral do sistema. Ademais, afirmam que, ao determinar que a lei facilite a conversão da união estável em casamento, não seria possível estender os seus efeitos à união homoafetiva, pois igualmente não seria possível, de acordo com as demais normas do ordenamento, o casamento homoafetivo.

Assim, postulam no sentido de que a atuação do Legislativo seria elemento imprescindível para que a união homoafetiva alcançasse o status jurídico de entidade familiar, pois a extensão do conceito de união estável pela via jurisprudencial provocaria anomalias no sistema e implicaria uma perda na objetividade conceitual deste instituto. Sobre a imprescindibilidade da atuação legiferante, exemplificativamente: 
A heterossexualidade é a essência do casamento. Tanto que a melhor doutrina entende ser ato inexistente a união que se oficialize entre pessoas do mesmo sexo. O mesmo entendimento aplica-se à união estável, logo, enquanto não houver lei que reconheça tal direito, não pode o julgador, cuja tarefa é aplicar a norma posta, ignorar os limites legais para tutelá-lo. $[\ldots]$

Não há, em nosso ordenamento jurídico, amparo legal à união estável homoafetiva, o que impossibilita ao Judiciário acatá-la, sob pena de funcionar com o legislador positivo, em afronta ao princípio constitucional da separação dos poderes. (Voto vencido do Des. Francisco Vicente. Apelação 015307317.2008.8.26.0000, Tribunal de Justiça do Estado de São Paulo, $11^{\text {a }}$ Câmara de Direito Público, data de julgamento: 27/04/2009, grifos acrescidos)

Após esta breve análise, em que identificamos as principais controvérsias suscitadas nos debates realizados pelos tribunais estaduais brasileiros, consideramos estar suficientemente descrita a situação em que se encontrava a jurisprudência pátria sobre as uniões homoafetivas no período anterior ao julgamento da ADI 4.177, pelo que podemos passar a avaliar a decisão do Supremo Tribunal Federal no julgamento da referida ação.

\section{Avaliação da decisão do Supremo Tribunal Federal}

A discussão relativa às uniões homoafetivas chegou ao Supremo Tribunal Federal, pela primeira vez, por meio da ADI 3.300, ${ }^{11}$ proposta pela Associação da Parada do Orgulho dos Gays, Lésbicas, Bissexuais e Transgêneros de São Paulo. Naquela ação, questionava-se a interpretação ordinariamente adotada pelos tribunais brasileiros acerca da Lei das Uniões Estáveis (Lei n. 9.278/96), na qual somente se incluía os relacionamentos heteroafetivos. Contudo, o Código Civil de 2002 revogou o ato normativo impugnado, pelo que a ação foi extinta sem resolução do mérito em razão da perda superveniente do objeto.

Contudo, a matéria foi novamente suscitada por ocasião da ADPF 132, proposta pelo Governador do Estado do Rio de Janeiro, em face do Estatuto dos Servidores Civis do estado e das decisões proferidas no Estado do Rio de Janeiro e em outras unidades federativas, que negavam às uniões homoafetivas os direitos pacificamente reconhecidos aos casais em união estável. Subsidiariamente, o autor pleiteou o recebimento da ADPF como ADI, a fim de conferir interpretação conforme a Constituição ao art. 1.723 do Código Civil, conversão que foi promovida pelo relator.

Por fim, o Procurador-Geral da República propôs nova ADPF, que ao ser analisada pelo Ministro Gilmar Mendes, no exercício da presidência do tribunal, foi convertida na ADI 4.277. Na referida ação, a Procuradoria requereu que o Supremo Tribunal Federal declarasse: “a) que é obrigatório o reconhecimento, no Brasil, da união entre 
pessoas do mesmo sexo, como entidade familiar, desde que atendidos os requisitos exigidos para a constituição da união estável entre homem e mulher; e b) que os mesmos direitos e deveres dos companheiros nas uniões estáveis estendam-se aos companheiros nas uniões entre pessoas do mesmo sexo".

As duas últimas ações de controle abstrato de constitucionalidade foram reunidas sobre a relatoria do Ministro Carlos Ayres Britto e julgadas em conjunto pelo Plenário da Corte Constitucional nos dias 4 e 5 de maio de 2011.

Inicialmente é preciso enfrentar os óbices que normalmente se invocam contra a possibilidade de a Corte Constitucional enfrentar matéria de tamanha densidade e relevância social. Em regra, os opositores da tramitação do tema pela via judicial reclamam que o Poder Judiciário não poderia escrever direitos fundamentais, substituindo a vontade do poder constituinte originário, que optou por não regular o assunto em debate e deixá-lo sob a análise do legislador ordinário.

Essa questão foi especialmente enfrentada no julgamento, sendo possível encontrar a síntese da conclusão emanada do Supremo Tribunal Federal neste trecho do voto proferido pelo Ministro Gilmar Mendes:

Não seria extravagante, no âmbito da jurisdição constitucional, diante inclusive das acusações de eventual ativismo judicial, de excesso de intervenção judicial, dizer que melhor saberia o Congresso encaminhar esse tema, como têm feito muitos parlamentos do mundo todo. Mas é verdade, também, que o quadro que se tem, como já foi aqui escrito, é de inércia, de não decisão por razões políticas várias que não valem, que não devem ser aqui rememoradas, nós conseguimos então identificar.

É evidente, também, me parece, que aqui nós não estamos a falar apenas, Senhor Presidente, da falta de uma disciplina que permita o desenvolvimento de uma política pública. Nós estamos a falar, realmente, de direitos fundamentais básicos. (Grifos acrescidos)

Em verdade, há dois argumentos principais invocados para justificar o papel da Corte no processo decisório da questão em análise.

O primeiro deles surge a partir da constatação de que o problema colocado em julgamento refere-se a uma questão principiológica. Como sabido, os princípios constitucionais ocupam papel de destaque no mundo jurídico e não possuem condições determinadas para sua aplicação. Dessa forma, a matéria submetida à análise da Corte consiste justamente em, a partir de determinada situação fática, reconhecer se os princípios invocados são ali aplicáveis.

Em verdade, discutir a aplicação de princípios é a tarefa que assume maior grau de importância nas Cortes Constitucionais ao redor do mundo, configurando-se como verdadeira questão de direito. Nesse aspecto, depreende-se do voto da Ministra Cármen 
Lúcia, fazendo referência a Bobbio, cuja discussão não se pauta pela conquista de novos direitos, mas pela efetivação de direitos já conquistados.

Em segundo lugar, a não atuação do legislador é identificada como situação causadora de uma proteção insuficiente aos direitos fundamentais dos casais homoafetivos, o que reclama a atuação da Corte. Conforme apontado pelo Ministro Joaquim Barbosa, a inércia legislativa causou um insustentável descompasso entre o mundo dos fatos e o universo do direito, hipótese na qual "as Corte Supremas e Constitucionais devem fazer a ponte entre o mundo do direito e a sociedade".

Outro aspecto importante no qual o Supremo Tribunal Federal teve de se debruçar foi a discussão acerca da adequada técnica de decisão em controle de constitucionalidade aplicável ao caso.

Evidentemente, a simples declaração de inconstitucionalidade com pronúncia de nulidade não seria suficiente, pelo contrário, geraria efeitos desastrosos. ${ }^{12}$ De fato, é nítido que a pretensão dos interessados que suscitaram a atuação da Corte não era ver declarada a inconstitucionalidade do dispositivo do Código Civil que rege as uniões estáveis, mas a de possibilitar que esta norma fosse interpretada de forma abrangente o suficiente para incluir as uniões homoafetivas. ${ }^{13}$

Contudo, o pedido de interpretação conforme a Constituição, formulado nas ações diretas de inconstitucionalidade, encontrou no mínimo dois obstáculos.

Inicialmente, contata-se que o texto infralegal questionado é mera repetição daquilo que consta no próprio texto da Constituição. Assim, sendo certo que jamais se admitiu em nosso sistema jurídico a possibilidade da inconstitucionalidade do texto constitucional originário, ${ }^{14}$ o Tribunal estaria realizando, indiretamente, interpretação da Constituição conforme a Constituição.

Por segundo, sabe-se que a interpretação conforme a Constituição parte das interpretações possíveis em um texto com múltiplos sentidos para escolher quais dessas interpretações são, ou não, constitucionais. Contudo, no caso em análise, partiuse de um texto com linguagem extremamente clara para atribuir-lhe uma interpretação que dificilmente poderia ser considerada entre "sentidos possíveis" da norma.

Ante a esses problemas, a Corte Constitucional necessitou construir argumentativamente uma solução, cujo centro consta no voto do Ministro Gilmar Mendes. Ao analisar a questão, o ministro acentuou a dificuldade técnica da decisão, afirmando que "não é necessário muito esforço hermenêutico para se constatar, de pronto, que o pedido, tal como formulado, poderia suscitar sérios questionamentos quanto aos limites da interpretação conforme a Constituição”.

O julgador então avalia que, em muitos casos, o Supremo Tribunal Federal não distingue claramente entre a interpretação conforme a Constituição, limitada negativamente pelos sentidos literais do texto, e a "decisão interpretativa modificativa desses sentidos originais postos pelo legislador”, buscando, por quaisquer dessas técnicas, solucionar a inconstitucionalidade no caso concreto. 
Dessa forma, conclui o Ministro, o papel da Corte Constitucional está se distanciando do dogma do legislador negativo e dirigindo-se à linha jurisprudencial das decisões interpretativas com efeitos aditivos. De toda a sorte, a solução apresentada é incompleta, não sendo possível delimitar com clareza os limites da atuação da Corte ao interpretar a Constituição, seja pela interpretação conforme ou pela interpretação aditiva.

No mérito, os fundamentos adotados exprimiram razoável consenso, havendo, contudo, substancial diferença nas conclusões a que chegaram os julgadores.

O eixo da decisão está na argumentação sistêmico-principiológica. De fato, a Corte acentua o caráter sistêmico da Constituição a fim de evidenciar a contradição existente entre a literalidade do art. 226, $\S 3^{\circ}$, do texto constitucional e o restante do diploma normativo, sobretudo quando se confere ao referido dispositivo uma interpretação que objetive excluir a possibilidade de existência de um modelo familiar que abrigue as relações homoafetivas. A partir desse contraste, os ministros promovem uma compatibilização hermenêutica, utilizando-se primordialmente dos princípios constitucionais.

O próprio desenvolvimento do instituto familiar, trazido ao debate como argumento histórico pelo Ministro Marco Aurélio, ${ }^{15}$ reforça a compreensão de que a atual Constituição da República, que promoveu expressivos avanços no campo da pluralização dos modelos familiares, não poderia tornar-se uma cláusula de barreira para o desenvolvimento de um processo por ela mesmo impulsionado.

Acerca dessa mudança no paradigma familiar, destacou o Ministro Luiz Fux:

Dessa forma, o conceito constitucional pós-1988 de família despiu-se de materialidade e restringiu-se a aspectos meramente instrumentais, merecendo importância tão-somente naquilo que se propõe à proteção e promoção dos direitos fundamentais dos indivíduos. Em síntese, não pode haver compreensão constitucionalmente adequada de família que aceite o amesquinhamento de direitos fundamentais.

É justamente a partir dessa perspectiva que o Supremo Tribunal Federal aplicou ao caso os princípios da igualdade, da liberdade e da não discriminação.

Se, por certo, os princípios são normas que orientam a interpretação das regras do ordenamento, a aplicação da regra em agressão frontal a princípios aos quais ela se subordina gera uma incongruência que deve ser solucionada interpretativamente para correta aplicação do direito ao fato. Este processo, para além da simples subsunção, exige uma construção argumentativa da premissa normativa.

Assim, ante a insegurança jurídica gerada pelas excessivas decisões contraditórias concernentes à matéria, o Supremo Tribunal Federal buscou exercer, além do papel de Corte Constitucional, a função de instância superior do Poder Judiciário responsável pela uniformização da jurisprudência constitucional, conforme o modelo de organização da jurisdição adotado pela Constituição de 1988. 
Há, dessa forma, um componente institucional na decisão prolatada, fato confirmado pela eficácia erga omnes e pelo efeito vinculante conferido por lei às decisões em controle concentrado de constitucionalidade, como ocorre na hipótese.

Contudo, a despeito da aparente convergência entre o entendimento dos membros do Tribunal, a conclusão alcançada por cada um dos ministros não foi idêntica. As margens amplas que possui o instituto da interpretação conforme à Constituição torna possível uma variedade de soluções com diferenças não muito abordadas, mas que necessitam ser ressaltadas.

Houve consenso entre os julgadores de que as relações homoafetivas são um fato da vida que, sob pena de ofensa a princípios constitucionais, devem ser tuteladas pelo direito por meio da disciplina que rege as relações familiares. Entretanto, no momento de determinar quais normas específicas devem incidir sobre essas relações, surgiu uma significante divergência.

A primeira opinião, que consta do voto relator, defende que a tutela jurídica das uniões homoafetivas deve ser dar "segundo as mesmas regras e com as mesmas consequências da união estável heteroafetiva”. Segundo esse entendimento, como decorrência direta do julgamento da Suprema Corte, os casais homoafetivos adquiririam direito à totalidade do regime jurídico aplicável à união estável, inclusive quanto às suas consequências, o que inclui a possibilidade de conversão em casamento e a adoção conjunta.

Nessa linha de pensamento, a Corte estaria a promover uma analogia perfeita, criando a possibilidade de uma união estável homoafetiva a partir da aplicação direta dos princípios constitucionais. Tratar-se-ia, portanto, de uma mutação no instituto da união estável.

De outro lado, na linha inaugurada pelo Ministro Ricardo Lewandowski, defende-se que o papel da Corte seria o de afastar qualquer interpretação que tente utilizar a Constituição para negar reconhecimento jurídico às uniões homoafetivas. Dessa forma, abrir-se-ia a possibilidade de uma integração analógica dessas relações com a união estável "apenas naquilo em que são assemelhados, descartando-se aqueles que são próprios da relação entre pessoas de sexo distinto".

Essa opinião foi corroborada pelos Ministros Gilmar Mendes e Cezar Peluso. Esse último, ao proferir seu voto, ressaltou:

De modo que, na solução da questão posta, a meu ver e de todos os Ministros da Corte, só podem ser aplicadas as normas correspondentes àquelas que, no Direito de Família, se aplicam à união estável entre o homem e a mulher. Mas nem todas, porque não se trata de situações absolutamente idênticas, senão, como todos tratamos de equiparação, e equiparação porque não há, na verdade, igualdade, portanto, é preciso respeitar aquilo que cada instituição, em si, tem de particular, não apenas por sua natureza 
extrajurídica, mas também pela própria natureza normativa de cada qual. (Grifos acrescidos)

A despeito da controvérsia, todos os ministros votaram com o Relator, proclamando-se como resultado do julgamento que "Os ministros desta Casa de Justiça, ainda por votação unânime, acordam em julgar procedentes as ações, com eficácia erga omnes e efeito vinculante, com as mesmas regras e consequências da união heteroafetiva" (Grifos acrescidos)

A ausência de um debate mais incisivo sobre as divergências laterais provocou a perpetuação da incerteza acerca do correto regime jurídico aplicável às uniões homoafetivas. Embora a decisão da Corte Constitucional determine expressamente a adoção das mesmas regras e das mesmas consequências previstas para a união estável, grande debate se instaurou na doutrina e na jurisprudência acerca do alcance desta decisão. ${ }^{16}$

Portanto, certo é que o Tribunal deveria ter se debruçado melhor sobre o tema, proferindo uma decisão tecnicamente mais precisa e menos vaga. Naquele momento, deveriam ter sido analisadas cada uma das consequências diretas da equiparação entre as uniões homoafetivas e as uniões estáveis, evitando assim a contraditória conclusão de que o julgamento foi unânime, mas divergente.

Ao que tudo indica, a decisão do Supremo Tribunal Federal não foi terminativa, mas apenas um primeiro posicionamento da Corte sobre a matéria, que ainda gerará muitos debates no Pretório Excelso.

Com efeito, observa-se que um novo capítulo deste romance será escrito em breve, no julgamento da ADI 4.966/DF. Nessa ação será discutida a constitucionalidade da Resolução n. 175 do Conselho Nacional de Justiça, ${ }^{17}$ que, fundamentando-se na decisão que acabamos de avaliar, tornou obrigatória às autoridades competentes a celebração de casamento civil entre pessoas de mesmo sexo.

A Corte, enfim, será provocada a responder, de forma direta, se é possível extrair de seu julgamento anterior a existência, no ordenamento jurídico brasileiro, do casamento civil entre pessoas do mesmo sexo.

Esta nova ação está sob a relatoria do Ministro Gilmar Mendes, que, considerando a relevância da matéria, adotou o procedimento abreviado para o julgamento da controvérsia. É interessante perceber que, ao votar na ADI 4.277, o Ministro Gilmar salientou:

Neste momento, limito-me a reconhecer a existência da união entre pessoas do mesmo sexo, por fundamentos jurídicos próprios e distintos daqueles explicitados pelo Ministro Ayres Britto e, com suporte na teoria do pensamento possível, determinar a aplicação de um modelo de proteção semelhante - no caso, o que trata da união estável, naquilo que for cabível, 
nos termos da fundamentação aqui apresentada, sem me pronunciar sobre outros desdobramentos. (Grifos acrescidos)

De fato, o julgamento gerou seus naturais desdobramentos e agora a Corte é chamada a se pronunciar de forma mais direta e clara sobre eles. Enquanto isso, o regime jurídico das uniões homoafetivas permanece entre debates e contradições, aguardando que o Supremo Tribunal complete sua decisão e esclareça exatamente o que significa "naquilo que for cabível".

\section{CONCLUSÕES}

As uniões homoafetivas, embora sejam fatos sociais recorrentes, não recebem no ordenamento jurídico brasileiro qualquer tratamento normativo. Assim, as controvérsias em torno do tema, em consequência da inércia legislativa, provocam grandes discussões no âmbito judicial.

Em um primeiro momento, a posição jurisprudencial negava qualquer efeito jurídico à união homoafetiva, classificando-a como um "nada jurídico". Qualquer pretensão fundada nesse tipo de relação nem sequer era discutida, por considerar-se um pedido juridicamente impossível.

A crescente aprovação social a este tipo de relacionamento, bem como o avanço do princípio da não discriminação, provocou a abertura do direito ao reconhecimento das uniões homoafetivas como relações aptas a gerar efeitos jurídicos. Tendo em vista a falta de regulamentação específica, os tribunais passaram a integrar o ordenamento por meio de processos analógicos.

A partir da interpretação literal dos dispositivos que tratam da família e da concepção tradicional de entidades familiares, as uniões homoafetivas foram tuteladas como sociedades de fato, sendo regidas pela disciplina contratual e sujeitas à jurisdição civil contenciosa.

Na última década, com o impacto da constitucionalização do direito de família e o desenvolvimento de ferramentas teóricas como o princípio da afetividade, houve uma tentativa de deslocar a matéria relativa às uniões homoafetivas para o campo do direito de família por meio da equiparação dessas entidades com a união estável heteroafetiva, tese que encontrou bastante resistência, iniciando um intenso debate argumentativo.

Nesse contexto, os tribunais brasileiros adotaram posicionamentos divergentes uns com os outros, e entre seus próprios julgados, ao decidir sobre a matéria. Da mesma forma, a doutrina possuía defensores em ambos os lados, não havendo qualquer inovação legislativa significativa acerca do tema.

Um intenso debate foi travado entre os defensores do argumento literal, que defendiam uma interpretação estrita das disposições acerca da união estável, e os que se posicionavam por uma argumentação princípio-sistêmica, que com base em princípios 
constitucionais como a igualdade e a liberdade atribuíam uma interpretação ampla a tais disposições, a fim de abranger as uniões homoafetivas.

Em ambas as correntes havia um apelo ao argumento teleológico, pois os representantes de cada corrente interpretativa buscavam, uns pela literalidade e outros pela organicidade, encontrar a real intenção da norma constitucional que criou a união estável.

O impasse entre os dois posicionamentos não foi superado pelo decurso do tempo, razão pela qual a Corte Constitucional foi provocada, por meio de uma Ação Direta de Constitucionalidade, a pacificar o entendimento acerca do art. 226, IV, da Constituição Federal.

No julgamento da ADI 4.277, em conjunto com a ADPF 132, o Supremo Tribunal Federal, após enfrentar questões relativas à legitimidade para atuar na matéria, posicionou-se a favor de uma interpretação mais ampla do referido dispositivo, rechaçando expressamente o argumento literal e afastando a analogia da união homoafetiva com uma simples sociedade de fato.

Destaca-se na decisão da Corte Suprema a consolidação de uma nova perspectiva da família e da sua função na sociedade, que se volta para a plena realização dos direitos fundamentais, sobretudo a dignidade da pessoa humana. Além disso, é nítido no julgamento o entendimento de que o direito à liberdade alberga o direito ao livre planejamento da vida familiar, devendo cada qual constituir sua família da forma que melhor propicie o desenvolvimento de seus membros a partir do afeto mútuo.

Entretanto, no que tange especificamente ao regime legal que deve ser aplicado às uniões homoafetivas, embora o tribunal tenha declarado que o reconhecimento jurídico dessas uniões deveria ser feito com as mesmas regras e consequências da união estável, os desdobramentos dessa conclusão evidenciaram a imprecisão do comando dispositivo da decisão.

De fato, não houve unanimidade para afirmar que o regime jurídico das uniões estáveis é plenamente aplicável às uniões homoafetivas. No entanto, não existe um pronunciamento claro sobre em quais pontos é possível, ou não, aplicar a interpretação analógica. Assim, o tribunal certamente será provocado a esclarecer sua jurisprudência, definindo com maior precisão o verdadeiro sentido e o real alcance de seu julgado. 


\section{NOTAS}

* Artigo elaborado em conclusão ao Programa de Iniciação Científica da Universidade de Brasília (ProIC/UnB) 2013, sob orientação e coautoria de professor.

1 Manuel Atienza assinala que a análise de uma decisão objetiva compreender a estrutura dos argumentos utilizados por ela, ao passo que a avaliação parte dessa compreensão e busca que se assuma uma postura crítica a respeito dos argumentos adotados: "el análisis de una argumentación suele ser el paso previo a su evaluación. Necesitamos (o queremos) entender la argumentación que otro ha hecho para así poder evaluarla y adoptar alguna actitud al respecto: aceptar que la decisión así argumentada está justificada, discrepar de la misma y escribir un artículo doctrinal mostrando por qué se trata de una argumentación equivocada, plantear un recurso 'explotando' precisamente los errores argumentativos de la decisión, etc." (ATIENZA, 2013, p. 484)

2 Acerca do tratamento jurídico atribuído às uniões homoafetivas ao redor do mundo: Atkin (2011).

3 Registre-se que durante a pesquisa foram encontrados atos normativos que tratavam das uniões homoafetivas, sobretudo no que toca aos direitos previdenciários e dos servidores públicos. Porém, no que tange ao direito civil propriamente dito, cuja competência legislativa é constitucionalmente atribuída ao Congresso Nacional, não houve qualquer ação efetiva. Vide Lei estadual n. 5.260/2008 do Rio de Janeiro (arts. 14 ss.) e Lei estadual n. 13.549/2009 de São Paulo (art. $5^{\circ}$ )

4 Nos termos do art. 102, § $2^{\circ}$, da Constituição Federal, as decisões do Supremo Tribunal Federal, nas ações de controle concentrado de constitucionalidade, possuem eficácia contra todos e efeito vinculante, relativamente aos demais órgãos do Poder Judiciário e à administração pública direta e indireta, nas esferas federal, estadual e municipal.

5 Os embargos declaratórios, por constituírem meio recursal voltado à solução de contradições, omissões ou obscuridades no acórdão embargado, não acrescentam, em regra, nenhum conteúdo novo à decisão. Contudo, na excepcional hipótese de um recurso desse tipo ter sido provido com efeitos modificativos, alterando o resultado da decisão anterior, considerou-se, para efeitos da pesquisa, uma nova decisão.

6 Apelação 4845559-52.2009.8.13.0024, data de julgamento: 25/11/2009.

7 "Encontra-se presente a possibilidade jurídica do pedido quando o ordenamento jurídico não veda o exame da matéria por parte do Judiciário. [...] Constitui erro grosseiro argumentar que o pedido do autor é juridicamente impossível porque o direito material não o ampara. Se o direito não ampara a pretensão, o caso é de improcedência." (DONIZETTI, 2007, p. 24-25, grifos acrescidos)

8 Apelação 2007.032992-5, data de julgamento: 18/03/2008.

9 Nem sempre os acórdãos são claros na fundamentação que apoiam suas conclusões. Considerou-se a decisão favorável à equiparação sempre que, de alguma forma, o tribunal reconheceu o caráter familiar das uniões homoafetivas e lhes aplicou alguma disposição normativa referente à união estável.

10 Apelação Cível 2008.01.1.129519-6, data de julgamento: 25/08/2010.

11 Disponível em: <http://www.stf.jus.br/portal/processo/verProcessoAndamento.asp?numero=3300\&classe= ADI-MC\&codigoClasse $=0$ \&origem $=J U R \&$ recurso $=0 \&$ tipoJulgamento $=M>$. Acesso em 30/06/2013.

12 Trata-se da técnica básica do controle de constitucionalidade brasileiro, que consiste no reconhecimento da incompatibilidade da norma infraconstitucional frente à Constituição e, por consequência, sua retirada do ordenamento jurídico com efeitos ex tunc.

13 A própria petição inicial da ADI 4.277 apresenta de forma clara o pedido de interpretação conforme à Constituição, portanto, sem declaração de nulidade.

14 Vide a ADI 4.097, na qual se indeferiu a petição inicial de ação direta em face de norma do texto constitucional originário. O pedido foi julgado juridicamente impossível. 
15 Após um apanhado acerca do desenvolvimento histórico do instituto familiar, concluiu o Ministro Marco Aurélio: "O processo evolutivo encontrou ápice na promulgação da Carta de 1988. O Diploma é o marco divisor: antes dele, família era só a matrimonial, com ele, veio a democratização - o reconhecimento jurídico de outras formas familiares”.

16 A esse respeito, confira-se o capítulo referente à união estável em Diniz (2012).

17 "Art. $1^{\circ}$ É vedada às autoridades competentes a recusa de habilitação, celebração de casamento civil ou de conversão de união estável em casamento entre pessoas de mesmo sexo. Art. $2^{\circ} \mathrm{A}$ recusa prevista no artigo $1^{\circ}$ implicará a imediata comunicação ao respectivo juiz corregedor para as providências cabíveis. Art. $3^{\circ}$ Esta resolução entra em vigor na data de sua publicação." (Resolução n. 175 do CNJ)

\section{REFERÊNCIAS BIBLIOGRÁFICAS}

ATIENZA, Manuel. Curso de argumentación jurídica. Madrid: Trotta, 2013.

ATKIN, Bill (Org.). The international survey of family law. Bristol: Jordan Publishing Limited, 2011.

BRASIL. Código Civil brasileiro. Congresso Nacional, 2002. . Constituição da República Federativa do Brasil. Assembleia Nacional Constituinte, 1988.

DIAS, Maria Berenice. União homossexual: o preconceito \& a justiça. Porto Alegre: Livraria dos Advogados, 2000. DINIZ, Maria Helena. Curso de Direto Civil brasileiro: Direito de Família. 27. ed. São Paulo Saraiva, 2012. v. 5 DONIZETTI, Elpídio. Direito Processual Civil. Rio de Janeiro: Lumen Juris, 2007.

DWORKIN, Ronald. O império do direito. Tradução Jefferson Luiz Camargo. São Paulo: Martins Fontes, 2010. GONÇALVES, Carlos Roberto. Direito Civil Brasileiro: Direito de Família. São Paulo: Saraiva, 2009.

LÔBO, Paulo. Direito Civil: famílias. São Paulo: Saraiva, 2011.

MACCORMICK, Neil. Retórica e o Estado de Direito. Tradução Conrado Hubner Mendes e Marcos Paulo Veríssimo. Rio de Janeiro: Elsevier, 2008.

SUNDFELD, Carlos Ari. Fundamentos de direito público. São Paulo: Malheiros, 2005.

TOULMIN, Stephen. Os usos do argumento. Tradução Reinaldo Guarany. São Paulo: Martins Fontes, 2001.

Claudia Rosane Roesler

croeslerlaunb.br |

Doutora em Filosofia e Teoria Geral do Direito pela Universidade de São Paulo

Professora adjunta na Universidade de Brasília

\section{Paulo Alves Santos}

